\title{
Genetic Impairment of Frontocortical Endocannabinoid Degradation and High Alcohol Preference
}

\author{
Anita C Hansson 1,7, Francisco J Bermúdez-Silva ${ }^{2,7}$, Hanna Malinen ${ }^{3,7}$, Petri Hyytiä3, Irene Sanchez-Vera², \\ Roberto Rimondini $^{4,5}$, Fernando Rodriguez de Fonseca ${ }^{2}$, George Kunos ${ }^{6}$, Wolfgang H Sommer' \\ and Markus Heilig*, I,5
}

\begin{abstract}
'Laboratory of Clinical and Translational Studies, NIAAA, National Institutes of Health, Bethesda, MD, USA; ${ }^{2}$ Fundation IMABIS, Malaga, Spain; ${ }^{3}$ National Public Health Institute, Helsinki, Finland; ${ }^{4}$ Department of Pharmacology, University of Bologna, Bologna, Italy; ${ }^{5}$ Department of Clinical Neuroscience, Karolinska Institute, Stockholm, Sweden; ${ }^{\circ}$ Laboratory of Neuroendocrinology, NIAAA, Bethesda, MD, USA
\end{abstract}

\begin{abstract}
Endocannabinoid signaling has recently been implicated in ethanol-seeking behavior. We analyzed the expression of endocannabinoidrelated genes in key brain regions of reward and dependence, and compared them between the alcohol-preferring AA (Alko Alcohol) and nonpreferring ANA (Alko Non-Alcohol) rat lines. A decreased expression of fatty acid amidohydrolase (FAAH), the main endocannabinoid-degrading enzyme, was found in prefrontal cortex (PFC) of AA rats, and was accompanied by decreased enzyme activity in this region. Binding of the endocannabinoid-cannabinoid I (CBI) receptor ligand ${ }^{3}[\mathrm{H}] \mathrm{SRI} 4 \mathrm{I} / \mathrm{I}$ A , and [35S]GTP $\gamma \mathrm{S}$ incorporation stimulated by the CBI agonist WIN 55,212-2 were downregulated in the same area. Together, this suggests an overactive endocannabinoid transmission in the PFC of AA animals, and a compensatory downregulation of CBI signaling. The functional role of impaired FAAH function for alcohol self-administration was validated in two independent ways. The CBI antagonist SRI4I7I6A potently and dose-dependently suppressed self-administration in AA rats when given systemically, or locally into the PFC, but not in the striatum. Conversely, intra-PFC injections of the competitive FAAH inhibitor URB597 increased ethanol self-administration in nonselected Wistar rats. These results show for the first time that impaired FAAH function may confer a phenotype of high voluntary alcohol intake, and point to a FAAH both as a potential susceptibility factor and a therapeutic target.

Neuropsychopharmacology (2007) 32, I I7-126. doi:I0. I038/sj.npp. I 301034; published online 8 February 2006
\end{abstract}

Keywords: endocannabinoids; CBI; SRI4I7I6A; FAAH; alcoholism; prefrontal cortex

\section{INTRODUCTION}

Alcohol use is a major cause of morbidity and mortality. Recent data indicate that it accounts for appr. 85000 deaths/ year in the US alone, making it the number three externally modifiable cause of mortality (Mokdad et al, 2004). Genetic susceptibility factors interact with the environment to account for a considerable heritability in alcohol use disorders (Enoch and Goldman, 2001). Identification of heritable susceptibility factors offers a promise of improved and ultimately individualized pharmacological treatment in this disorder, a promise which is in part beginning to be realized (Oslin et al, 2003).

\footnotetext{
*Correspondence: Dr M Heilig, Laboratory of Clinical and Translational Studies, NIAAA, National Institutes of Health, Building 10, CRC, EI-5334, I 0 Center Dr MSC I I08, Bethesda, MD 20892-I I08, USA, Tel: + | 30 | 4359386, Fax: + | 301402 0445,

E-mail: markus.heilig@mail.nih.gov

${ }^{7}$ These authors contributed equally to this study.

Received 31 August 2005; revised 2 December 2005; accepted 8 December 2005

Online publication: 28 December 2005 at http://www.acnp.org/ citations/NPP I 2280505054 I/default.pdf
}

Endocannabinoid signaling has recently been shown to regulate various aspects of alcohol-seeking behavior (Hungund et al, 2003; Wang et al, 2003; Poncelet et al, 2003; Houchi et al, 2005; Colombo et al, 1998b; Rodriguez et al, 1999). The endocannabinoids, that is, arachidonyl ethanolamide (anandamide (AEA)) and arachidonyl glycerol (1-AG, 2-AG), are produced postsynaptically upon neuronal depolarization through hydrolysis of membrane lipids by $N$-acyl phosphatidylethanolamide-selective phospholipase D (NAPE-PLD). Following release, they diffuse back to the presynaptic neuron, where they act as shortrange modulators of synaptic activity by modulating neurotransmitter release. Central nervous system actions of endocannabinoids are largely mediated through cannabinoid 1 (CB1) receptors, which are abundantly expressed in the adult brain, and have a distribution consistent with the ability of cannabinoids to alter pain perception, affect motor function, impair cognition and memory, and stimulate feeding (Hohmann and Herkenham, 2000; Herkenham et al, 1990; Matsuda et al, 1993; Freund et al, 2003). Those actions are effectively inhibited by the CB1 receptor antagonist SR141716A (Rinaldi-Carmona et al, 1994), and are abolished in CB1 null mutants (Lutz, 2002). Endocan- 
nabinoid actions at $\mathrm{CB} 1$ receptors are predominantely terminated through degradation by fatty acid amidohydrolase (FAAH), and to a smaller extent by monoacylglycerol lipase (MAGL) (Freund et al, 2003).

Animal models based on selective breeding for excessive ethanol drinking have demonstrated a utility for identifying and validating novel alcoholism treatment targets (McBride and Li, 1998). The alcohol-preferring AA (Alko Alcohol) and the alcohol-avoiding ANA (Alko Non-Alcohol) rat lines are among the best-established selection-based models, and have been bidrectionally bred for high and low alcohol consumption, respectively, for over 90 generations (Sinclair et al, 1989). AA rats also share some interesting behavioral traits with early onset alcoholism, which has a distinct heritability and pharmacogenomic profile (Johnson et al, 2000; Cloninger, 1987; Möller et al, 1997). The AA and ANA lines have diverged with respect to several neurochemical measures (Sinclair et al, 1989; Gianoulakis et al, 1992; Arlinde et al, 2004), but the factors causing differential alcohol self-administration between them remain largely unknown.

Here, we therefore asked whether genetic differences between alcohol-preferring AA and alcohol-nonpreferring ANA rats include the endocannabinoid system, and whether such differences are of functional importance for the differential alcohol self-administration of the two lines.

\section{MATERIALS AND METHODS}

\section{Animals}

Ethanol-preferring AA (Alko, Alcohol; National Public Health Institute, Helsinki, Finland) and ethanol nonpreferring ANA (Alko, Non-Alcohol) male rats weighing 180$200 \mathrm{~g}$ at the beginning of the experiments were used. Animals were housed two/cage for ethanol self-administration experiments or otherwise in groups of four in a room with controlled temperature $\left(20 \pm 2{ }^{\circ} \mathrm{C}\right)$ and humidity $(55 \pm 5 \%)$ on a reverse 12 -h light-dark cycle (lights on at noon). Water and RM1 pellet food (SDS Ltd, Witham, UK) were available ad libitum in the home cage, except during initial training (see below). Operant sessions were during the dark phase of the light-dark cycle between 0800 and 1100. For in situ and in vitro studies drug-naïve animals were killed by decapitation, the brains were snap frozen in $-40^{\circ} \mathrm{C}$ isopentane and kept in $-70^{\circ} \mathrm{C}$. All experimental procedures using animals were carried out under the National Animal Welfare Act and were approved by the local ethical committees (National Public Health Institute's Animal Care and Use Committee; Stockholm South Animal Ethics Committee).

\section{CB1 Receptor mRNA In Situ Hybridization}

Brain sections $(10 \mu \mathrm{m})$ were taken at bregma levels $(1)+2.2$ to $+1.7 \mathrm{~mm}$, (2) +1.0 to $+0.2 \mathrm{~mm}$, (3) -0.4 to $-1.8 \mathrm{~mm}$, and (4) -2.3 to $-3.3 \mathrm{~mm}$ (Paxinos and Watson, 1986). The CB1 receptor riboprobe was generated by $\mathrm{PCR}$ and corresponds to nucleotides 1232-1272 of the cDNA sequence (NM_012784; (Matsuda et al, 1990)). Probe RNA synthesis and in situ hybridization have been described in detail recently (Caberlotto et al, 2003). The hybridized sections were exposed to Biomax ${ }^{\mathrm{TM}} \mathrm{MR}$ film (Kodak, NY, USA). Regions of interest were defined by anatomical landmarks as described in Paxinos and Watson (1986) and mean gray values from film autoradiograms were measured using a SAS Biovision image analyzing system (Avanzati, Milan, Italy). Optical density values (means \pm SEM) were obtained as described in Hansson et al (2003).

\section{Real-Time PCR and Cannabinoid Biochemistry}

Dissection of frozen brains was performed in a cryostat. Brains were placed in acrylic rat brain matrices, and $2 \mathrm{~mm}$ thick slices were obtained using brain matrix razor blades. The target brain regions were collected using a scalpel (prefrontal cortex (PFC) and dorsal hippocampus) or a sample corer (dorsal striatum). Location of the brain slices according to Paxinos and Watson (1986) were: PFC: first $2 \mathrm{~mm}$ anterior portion of the brain, bregma $5.20-3.20 \mathrm{~mm}$. Dorsal striatum: bregma 1.00 to $-1.00 \mathrm{~mm}$. Dorsal hippocampus: bregma -0.56 to $-2.56 \mathrm{~mm}$. Cerebellum: posterior end of brain eliminating pons and medulla oblongata, bregma -9.16 to $-14.60 \mathrm{~mm}$.

Real-time PCR for relative quantification of $C B 1, F A A H$, $M A G L$, and NAPE-PLD $m R N A$ expression. Total RNA from PFC, dorsal striatum and cerebellum was obtained using Trizol reagent (Gibco BRL Life Technologies, Baltimore, MD) according to the manufacturer's instructions. All RNA samples showed A260/280 ratios between 1.8 and 2.0. First-strand synthesis from each sample was carried out using random hexamer primer and $\mathrm{M}-\mathrm{MuLV}$ reverse transcriptase (Roche Applied Science, Indianapolis, USA) according to manufacturer's instructions. Negative control reactions omitted reverse transcriptase. Resulting cDNAs were used as the template for real-time quantitative PCR, which was performed on the LightCycler instrument (Roche) with the SYBR Green I detection format. The following primers were used (Accession numbers from NCBI database in parenthesis): CB1 (NM_012784) forward: $5^{\prime}$-agacctcctctacgtgggctcg- $3^{\prime}$, reverse: $5^{\prime}$-gtacagcgatggccag ctgctg-3' (314 bp product); FAAH (U72497) forward: $5^{\prime}$-gttacagagtggagagctgtc- $3^{\prime}$, reverse: $5^{\prime}$-gagggttactgcagt caaagc-3' (344 bp product); MAGL (NM_138502) forward: $5^{\prime}$-catggagctggggaacactg- $3^{\prime}$, reverse: $5^{\prime}$-ggagatggcaccgccatg gag- $3^{\prime}$ (240 bp product); NAPE-PLD (AB112351) forward: $5^{\prime}$-ggagcttatgagccaaggtg- $3^{\prime}$, reverse: $5^{\prime}$-actctccgtgcttcaggatg- $3^{\prime}$ (223 bp product). Endogenous control: beta-glucoronidase (b-Gluc, NM_017015) forward: 5'-tcctgtacaccaccctacc-3', reverse $5^{\prime}$-gccatcctcatccagaagac- $3^{\prime}$ (146 bp product). Primers were obtained from Proligo (Proligo France SAS, Paris, France).

Quantification was carried out on the basis of standard curves run simultaneously with unknown samples. $C B 1$, FAAH, MAGL, NAPE-PLD, and b-Gluc standards were generated by PCR amplification from control samples. The PCR product was run in a $1 \%$ agarose gel electrophoresis to verify fragment size and the absence of other contaminant fragments, quantified by $260 \mathrm{~nm}$ absorbance, and serially diluted to $10^{-5} \mathrm{pg} / \mu \mathrm{l}$. Several 10 -fold dilutions $\left(10^{-1}\right.$ to $\left.10^{-5}\right)$ were checked for optimal cycling on the LightCycler and three of them in an interval within which the samples fell were selected for standard curves. 
Each reaction was run in duplicate and contained $3 \mu \mathrm{l}$ of cDNA template, $3 \mathrm{mM} \mathrm{MgCl}_{2}$ and $0.5 \mu \mathrm{M}$ of primers in a final reaction volume of $20 \mu \mathrm{l}$. Cycling parameters were $95^{\circ} \mathrm{C}$ for $10 \mathrm{~min}$ to activate DNA polymerase, then $30-40$ cycles of $95^{\circ} \mathrm{C}$ for $10 \mathrm{~s}$, annealing temperature for $10 \mathrm{~s}\left(\mathrm{CB} 1: 62^{\circ} \mathrm{C}\right.$, FAAH: $41^{\circ} \mathrm{C}$, MAGL: $58^{\circ} \mathrm{C}$, NAPE-PLD: $57^{\circ} \mathrm{C}$, b-Gluc: $61^{\circ} \mathrm{C}$ ) and a final extension step of $72^{\circ} \mathrm{C}$ for $16 \mathrm{~s}$ in which fluorescence was acquired. Melting curves analysis was performed to ensure that only a single product was amplified. Data for CB1, FAAH, MAGL, NAPE-PLD were normalized for expression of b-Gluc. This internal standard was chosen based on first analyzing a panel of housekeeping genes that additionally included GAPDH, cyclophyllin, and SP1. Among these, b-Gluc, but not the other housekeeping gene transcripts were constant between AA and ANA rats.

Membrane-bound FAAH activity. Unlabeled AEA standard and $\left[{ }^{2} \mathrm{H}_{4}\right]$-labeled AEA were synthesized as described (Giuffrida et al, 2000). Tissues were homogenized in $50 \mathrm{mM}$ Tris buffer, $\mathrm{pH} 8$, containing $0.32 \mathrm{M}$ sucrose. Homogenates were centrifuged first at $1000 \mathrm{~g}$ ( $5 \mathrm{~min}$ ), the pellet discarded and the supernantant centrifuged at $45000 \mathrm{~g}$ ( $30 \mathrm{~min})$. The pellets obtained were solubilized at $0-4{ }^{\circ} \mathrm{C}$ in Tris buffer. Protein content in the membrane fraction was measured with the Bradford method. All tissue samples and membrane fractions were stored at $-70^{\circ} \mathrm{C}$ until used.

Membrane-bound FAAH activity was measured by using arachidonoyl-[1- $\left.{ }^{3} \mathrm{H}\right]$-ethanolamide as a substrate, and measuring metabolized $\left[{ }^{3} \mathrm{H}\right] \mathrm{AEA}$ (as $\left[{ }^{3} \mathrm{H}\right]$ ethanolamine) in the aqueous phase after chloroform extraction, as described (Desarnaud et al, 1995; Rodriguez et al, 2001). Standard amidohydrolase assays were carried out for $10 \mathrm{~min}$ at $37^{\circ} \mathrm{C}$ in $1 \mathrm{ml}$ of TRIS buffer $(50 \mathrm{mM}, \mathrm{pH} 7.5)$ containing membrane fraction $(100 \mu \mathrm{g}$ of protein) and a saturating $10 \mu \mathrm{M}$ concentration of tritiated AEA $(10000 \mathrm{dpm} / \mathrm{ml})$. Identical incubations were carried out in the absence of tissue: these 'blank' samples contained around $40 \mathrm{dpm} /$ sample that were subtracted from values obtained with tissue samples. Under these conditions, AEA hydrolysis was found to be linear with respect to time and protein concentration (Desarnaud et al, 1995).

Endocannabinoid levels. Brain regions PFC, caudate putamen and hippocampus from AA and ANA rats were dissected out from $2 \mathrm{~mm}$ coronal brain slices as recently described above for the biochemistry and assayed for AEA and 1-AG measurements as reported previously (Wang et al, 2003).

CB1 receptor binding. $\mathrm{CB} 1$-binding assays in membranes were performed as previously described (Hirst et al, 1996) using ${ }^{3}[\mathrm{H}] \mathrm{SR} 141716 \mathrm{~A}$ (Amersham, Little Chalfont, UK, $59 \mathrm{Ci} / \mathrm{mmol}$ ) as ligand. Assays were performed in triplicates for 60 at $30^{\circ} \mathrm{C}$ in a final volume of $0.5 \mathrm{ml}$ using a saturating concentration of SR-141716A (10 nM). Nonspecific binding was achieved with the inclusion of WIN-55,212-2 $10 \mu \mathrm{M}$. Results are expressed in $\mathrm{fmol} / \mathrm{mg}$ protein.

Cannabinoid-stimulated CB1 receptor-G-protein coupling in rat brain membranes. Cannabinoid-stimulated $\left.{ }^{35} \mathrm{~S}\right] \mathrm{GTP} \mathrm{P}_{\gamma}$ binding was determined as described previously
(Sim et al, 1996), using $20 \mu \mathrm{g}$ protein from membrane fractions. Membranes were incubated at $30^{\circ} \mathrm{C}$ for $1 \mathrm{~h}$ in assay buffer ( $50 \mathrm{mM}$ Tris- $\mathrm{HCl}, 3 \mathrm{mM} \mathrm{MgCl}_{2}, 0.2 \mathrm{mM}$ EGTA, $100 \mathrm{mM} \mathrm{NaCl}, 0.1 \mathrm{mg} / \mathrm{ml} \mathrm{BSA}, \mathrm{pH} 7.4$ ), with $10 \mu \mathrm{M}$ of WIN $55,212-2$ in the presence of $20 \mu \mathrm{M}$ GDP and $0.05 \mathrm{nM}$ $\left[{ }^{35} \mathrm{~S}\right] \mathrm{GTP} \gamma \mathrm{S}$ in a $1 \mathrm{ml}$ total volume. Basal binding was measured in the absence of agonist, and nonspecific binding was measured with $10 \mu \mathrm{M}$ guanidyl imidodiphosphate. The reaction was terminated by rapid centrifugation $(20000 \mathrm{~g})$ at $4{ }^{\circ} \mathrm{C}$, followed by two washes with cold Tris buffer. Bound radioactivity was determined by liquid scintillation spectrophotometry, at $95 \%$ efficiency for $\left[{ }^{35} \mathrm{~S}\right]$, after overnight extraction in $5 \mathrm{ml}$ Ecolite scintillation fluid. Data are reported as mean \pm SEM values of percentage of stimulation over basal levels.

\section{Behavioral Pharmacology}

Ethanol and saccharin self-administration. Ethanol selfadministration sessions were conducted in operant chambers (Lafayette Instrument, Lafayette, IN) equipped with two response levers. Responses at the appropriate lever activated a syringe pump, delivering a $0.1-\mathrm{ml}$ drop of $10 \%(\mathrm{w} / \mathrm{v})$ ethanol solution to the drinking cup between the levers in the center panel of the operant chamber. The MED-PC behavioral software (MED Associates Inc., Georgia, VT) was used for controlling the operant chambers and collecting data.

Rats were trained to orally self-administer ethanol using a saccharin-fading training protocol. Briefly, rats were placed on a 12-h water deprivation schedule for 3 consecutive days and trained to respond for a $0.1-\mathrm{ml}$ drop of $0.2 \%(\mathrm{w} / \mathrm{v})$ saccharin solution on both levers on a fixed ratio 1 reinforcement schedule. After the initial training, water deprivation was terminated, and animals had free access to food and water in their home cages throughout the subsequent training and testing. During the following sessions, responses on the right lever resulted in delivery of $5.0 \%$ ethanol $+0.2 \%$ saccharin $(\mathrm{w} / \mathrm{v})$ solution, whereas responses on the other lever were recorded but had no programmed consequences. Thereafter, the concentration of ethanol was first raised to $8 \%$ and then to $10 \%(\mathrm{w} / \mathrm{v})$, and the concentration of saccharin was decreased, until saccharin was completely eliminated from the drinking solution. The positions of the active and inactive levers were held constant during training and testing. All training and testing was conducted during 30-min daily sessions, 5 days a week. Animals were allowed to respond for $10 \%$ ethanol for 4-5 weeks before surgery.

Rats were trained to self-administer saccharin solution during daily 30-min sessions using the initial training phases described above, in the same operant chambers, and under identical experimental conditions. After the $0.2 \%$ (w/v) saccharin solution, the saccharin concentration was decreased to $0.1 \%$, and then to $0.05 \%$. Rats were allowed to respond for this saccharin solution for 2 weeks before further procedures.

Surgery. Rats were anesthetized with halothane-air mixture and positioned in a stereotaxic frame with the incisor bar adjusted at $3.3 \mathrm{~mm}$ below the interaural line. Bilateral 23-gauge guide cannulas were implanted $2 \mathrm{~mm}$ above the 
target areas in the PFC (AP 2.7 from bregma; $\mathrm{ML} \pm 0.6$; DV 3.2 from the skull surface) and striatum (AP 1.0 from bregma; $\mathrm{ML} \pm 3.0 ; \mathrm{DV} 5.0$ ), according to Paxinos and Watson (1986). Cannulas were secured to the skull with three anchor screws and dental cement, and were sealed with stylet wires to prevent occlusion. To alleviate postoperative pain, rats were administered once with buprenorphine $(0.03 \mathrm{mg} / \mathrm{kg}$ subcutaneously) immediately after the surgery. Animals were allowed to recover for at least a week before ethanol or saccharin self-administration sessions resumed.

Drug administration. For intraperitoneal injections, the CB1 receptor antagonist SR141716A (Sanofi Recherché, Montpellier, France) was suspended in propylene glycol, Tween 80 , and saline (ratio $1: 1: 18$ ) and administered $30 \mathrm{~min}$ before testing using a Latin square, within-subjects experimental design. For intracerebral microinjections $(0.5 \mu \mathrm{l})$, SR141716A was dissolved in $100 \%$ DMSO and diluted to a $75 \%$ solution with saline. The drug solutions were infused through 30-gauge injector cannulas connected to $10-\mu l$ microsyringes and extending $2 \mathrm{~mm}$ below the guides. Microinjections were delivered $20 \mathrm{~min}$ before the experimental sessions over a period of $45 \mathrm{~s}$ with an infusion pump. Another 60-s diffusion time was allowed before removal of injectors. To habituate the subjects to intracranial injections, the vehicle (75\% DMSO) was given as the first injection, followed by the 0,3 , and $6 \mu \mathrm{g}$ SR141716A doses using a within-subjects Latin square design. At least two baseline sessions were allowed between repeated injections. In order to exclude the possible nonspecific effects induced by the $75 \%$ DMSO vehicle on ethanol self-administration, repeated vehicle injections were performed in separate groups of rats with guide cannulas in the PFC $(n=7)$ or striatum $(n=7)$.

For intra-PFC microinjections $(0.5 \mu \mathrm{l})$ of the competitive FAAH inhibitor URB597 ((Kathuria et al, 2003); Cayman Chemicals, MI, USA), the drug was dissolved in 75\% DMSO and infused through 30-gauge injector cannulas connected to $10 \mu \mathrm{l}$ microsyringe and extending $2 \mathrm{~mm}$ below the guides. Microinjections were delivered $30 \mathrm{~min}$ before the experimental sessions over a period of $60 \mathrm{~s}$ with an infusion pump. Another $60 \mathrm{~s}$ diffusion time was allowed before removal of injectors. A between-subjects design was used and every animal received only one drug injection.

Blood ethanol concentrations. To verify the blood ethanol concentrations achieved during ethanol self-administration, blood samples $(10 \mu \mathrm{l})$ were obtained from the lateral tail vein immediately after a 30 -min ethanol self-administration session from a group of 20 rats. The ethanol concentrations from blood samples were determined with headspace gas chromatography.

Histology. After completion of behavioral testing, rats were anesthetized briefly with halothane, and killed by decapitation. The brains were fixed overnight with $10 \%$ formalin solution. The brains were frozen and sectioned at $100 \mu \mathrm{m}$ intervals, and the slides were stained with thionine. The positions of the injection cannulas were verified from the sections using a low-power light microscope and the atlas of (Paxinos and Watson, 1986).

\section{Statistical Analysis}

In situ hybridization, PCR, and biochemistry. Data were analyzed separately for each region by one-way ANOVA, because variances were homogenous within, but not between regions. Owing to the large number of regions examined in the in situ hybridization experiment, the ANOVA-computed probabilities for a treatment effect in each region were corrected for multiplicity of testing using the Holm sequentially corrected Bonferroni's method (Holm, 1979). Analysis of endocannabinoid measurements was carried out by Mann-Whitney $U$-test.

Ethanol and saccharin self-administration. The effects of SR141716A on ethanol and saccharin self-administration were expressed as the mean total number of responses at the active and inactive lever during the 30-min session and analyzed with one-way within-subjects ANOVA with repeated measures on dose. Following a significant main effect of dose, each individual drug dose was compared with the vehicle condition using a post hoc means comparison with Bonferroni's correction. The effects of URB597 were analyzed using one-way ANOVA followed by Tukey's multiple comparison post hoc test.

\section{RESULTS}

\section{Expression of Endocannabinoid-Related Genes}

A decreased expression of the two main enzymes that degrade endocannabinoids was found in the PFC of the AA line. The decrease was marked with respect to FAAH $(62 \%$, $\mathrm{F}[1,12]=18.1, p<0.001$; Figure 1$)$, and smaller with respect to MAGL $(19 \%, \mathrm{~F}[1,139]=4.81, p<0.05$; Figure 1$)$. Regional specificity was indicated by lack of differential expression in cerebellum (Figure 1) or striatum (where expression levels were an order of magnitude lower, and thus difficult to correctly visualize in the figure; $F A A H / b$-Gluc, mean \pm SEM: ANA $47.2 \pm 3.6$, AA $53.2 \pm 10.9$; and $M A G L / b-G l u c$ : ANA $132.6 \pm 19.1$, AA $161.0 \pm 41.2)$. Expression of $N A P E-P L D$ or $C B 1$ receptor transcript did not differ between the lines in any of the regions studied, that is PFC, striatum, or cerebellum (data not shown).

\section{FAAH Enzyme Activity}

In agreement with the expression data, FAAH activity at saturating conditions was about $30 \%$ lower in PFC $(\mathrm{F}[1,10]=9.63, p<0.01$; Figure 2$)$ but not in striatum or cerebellum of AA rats.

\section{Endocannabinoid Levels}

In PFC, both 1-AG and 2-AG levels were significantly higher in AA compared to ANA rats (pmole/mg tissue, mean \pm SEM, $n=8-10$ : 1 -AG: AA $5.3 \pm 0.36$ vs ANA $3.5 \pm 0.31$, $\mathrm{F}[1,14]=14.3, \quad p<0.002 ; 2-\mathrm{AG}:$ AA $0.47 \pm 0.04$ vs ANA $0.31 \pm 0.03, \mathrm{~F}[1,15]=11.8, p<0.005)$. PFC AEA levels did not differ between the lines (AA $0.36 \pm 0.05$ vs ANA $0.44 \pm 0.02, F[1,17]=1.8$, NS). No differences in endocannabinoid levels were found in striatum or cerebellum (data not shown). 

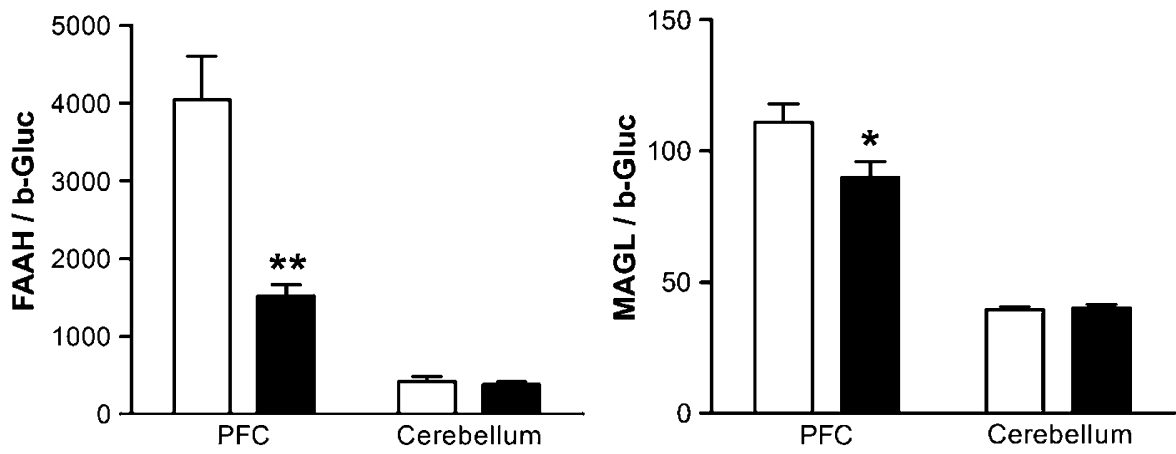

Figure I Real-time PCR expression data for FAAH and MAGL in prefrontal cortex and cerebellum of AA (black bars) and ANA (white bars) rats. Data are normalized to b-Gluc expression for each region and expressed as mean \pm SEM $* p<0.05$; *** $p<0.0$ I vs ANA group; $n=6-8 /$ group.

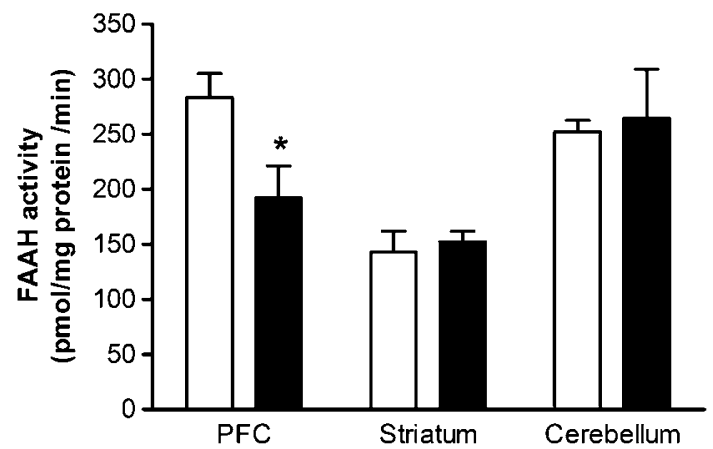

Figure 2 Biochemical analysis of brain membrane preparations from AA (black bars) and ANA (white bars) rats showing decreased membranebound FAAH activity levels in the PFC of AA rats using arachidonoyl$\left[\mathrm{I}-{ }^{3} \mathrm{H}\right]$-ethanolamide as a substrate (mean $\pm \mathrm{SEM}$ in $\mathrm{pmol} / \mathrm{mg}$ protein/min). * $p<0.05$ vs ANA group; $n=6-8$ /group.

\section{CB1 Receptor Availability and Function}

At saturating concentration of tritiated SR-141716A $(10 \mathrm{nM})$, membrane preparations from AA rats had $20 \%$ less binding sites in the PFC compared to ANA rats $(\mathrm{F}[1,13]=5.6, p<0.05)$, while densities did not differ in dorsal striatum, and cerebellum. In parallel, WIN 55,212-2stimulated incorporation of $\left[{ }^{35} \mathrm{~S}\right] \mathrm{GTP} \mathrm{S}_{\gamma} \mathrm{S}$ was lower in the PFC $(\mathrm{F}[1,12]=4.5, p<0.05)$ but not striatum or cerebellum of $\mathrm{AA}$ rats (Table 1$)$.

\section{CB1 Receptor Gene Expression}

The pattern of expression of $C B 1$ mRNA in both AA and ANA lines was consistent with previous studies (Mailleux and Vanderhaeghen, 1992; Hohmann and Herkenham, 2000; Matsuda et al, 1993) (Figure 3). No difference in $C B 1$ expression between the two lines was found in the PFC. In the caudate putamen, a dorso-mediolateral or dorso-ventrolateral gradient of CB1 mRNA intensity levels was observed, dependent on the bregma level. The strongest signal intensity in the caudate putamen was found rostrally in the mediolateral part (bregma level +1.0 to $+0.2 \mathrm{~mm}$, Figure 3 ) and more caudally in the ventrolateral part (bregma level -0.4 to $-1.8 \mathrm{~mm}$ ). Differential $C B 1$ expression between the lines was found in the caudate putamen at bregma level +1.0 to $+0.2 \mathrm{~mm}$ (mean optical density $\times 10^{3} \pm$ SEM, $n=8$ : AA $78 \pm 3$ vs ANA $106 \pm 6$;

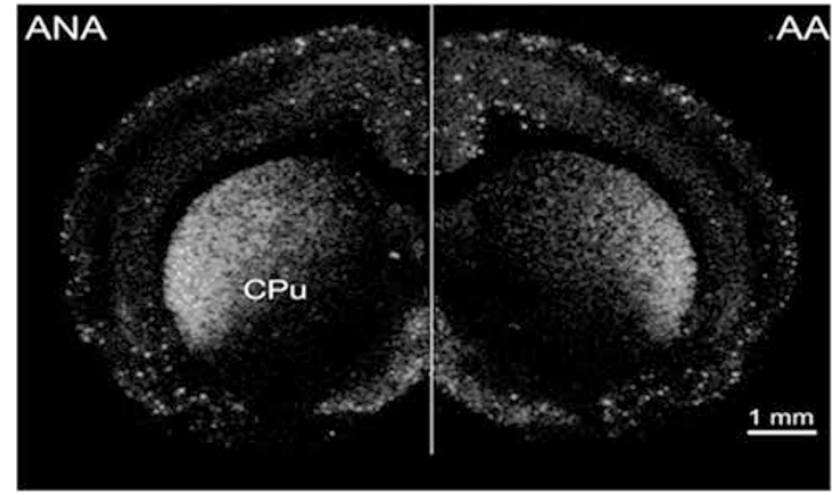

Figure 3 Darkfield photomicrographs from film autoradiograms of in situ hybridization showing lower expression levels of $C B /$ receptor in the caudate putamen (CPu) in AA (right) compared to ANA (left) rats. Bregma level $(+1.0 \mathrm{~mm})$, scale bar $=1 \mathrm{~mm}$.

Table I Density and Coupling of CBI Receptors in AA and ANA Rats

\begin{tabular}{lcccccc}
\hline & \multicolumn{2}{c}{ Density } & & \multicolumn{2}{c}{ Coupling } \\
\cline { 2 - 3 } \cline { 5 - 6 } Brain region & ANA & AA & & ANA & AA \\
\hline Prefrontal cortex & $680.0 \pm 52.0$ & $546.0 \pm 27.0 *$ & & $203.1 \pm 12.9$ & $170.5 \pm 9.6 *$ \\
Dorsal striatum & $2040.0 \pm 156.0$ & $1742.0 \pm 132.0$ & & $195.8 \pm 18.4$ & $161.2 \pm 8.9$ \\
Cerebellum & $1462.0 \pm 190.0$ & $1825.0 \pm 240.0$ & & $193.4 \pm 21.1$ & $187.4 \pm 17.3$
\end{tabular}

Left two columns: cannabinoid $\mathrm{CBI}$ receptor-binding sites measured with $\left[{ }^{3} \mathrm{H}\right]-S R|4| 7 \mid 6 \mathrm{~A}(10 \mathrm{nM})$. Data are means \pm SEM in fmol/mg protein. Right two columns: WIN 55,212-2 (I0 $\mu \mathrm{M})$ induced $\left[{ }^{35} \mathrm{~S}\right] \mathrm{GTP}, \mathrm{S}$ incorporation shown as percentage of stimulated binding (mean $\% \pm$ SEM). * $p<0.05$ vs ANA group; $n=6-8 /$ group.

$\mathrm{F}[1,14]=17.39$, Bonferroni's corrected $p<0.002)$. No CB1 expression differences were found in cingulate, frontal, or frontoparietal cortex (data not shown).

\section{Effect of CB1 Antagonist SR141716A on Ethanol Self-Administration in AA Rats}

AA rats showed reliable responding for both $10 \%(\mathrm{w} / \mathrm{v})$ ethanol and $0.05 \%(\mathrm{w} / \mathrm{v})$ saccharin. During a baseline 30 min session, self-administration resulted in delivery of 
$0.86 \pm 0.07 \mathrm{~g} / \mathrm{kg}$ of alcohol (mean $\pm \mathrm{SEM} ; n=20$ ), resulting in mean blood ethanol concentrations (BACs) of $5.85 \pm 0.85 \mathrm{mM}$ immediately after completion of the session. BACs were significantly correlated with the ethanol intake during the session (Pearson $r=0.84, p<0.01$ ), showing that the ethanol delivered was in fact consumed.

I.p. injections of SR141716A suppressed ethanol responding in a dose-dependent manner $(\mathrm{F}[3,33]=21.44$, $p<0.0001$; Figure 4). Injections into the PFC (Figure 5a) reproduced the systemic effect and significantly suppressed responding $(\mathrm{F}[2,16]=16.13, p<0.0001)$, whereas reductions by intrastriatal administration (Figure 5b) did not reach significance $(\mathrm{F}[2,18]=3.28$, NS). Microinjection sites for PFC and striatal injections are shown in Figure $5 \mathrm{c}$ and $d$, respectively. For SR141716A injections into the medial PFC, the cannula placements were verified within the region from 2.7 to $3.7 \mathrm{~mm}$ anterior to bregma. Placements for the intra-striatal injections were verified in

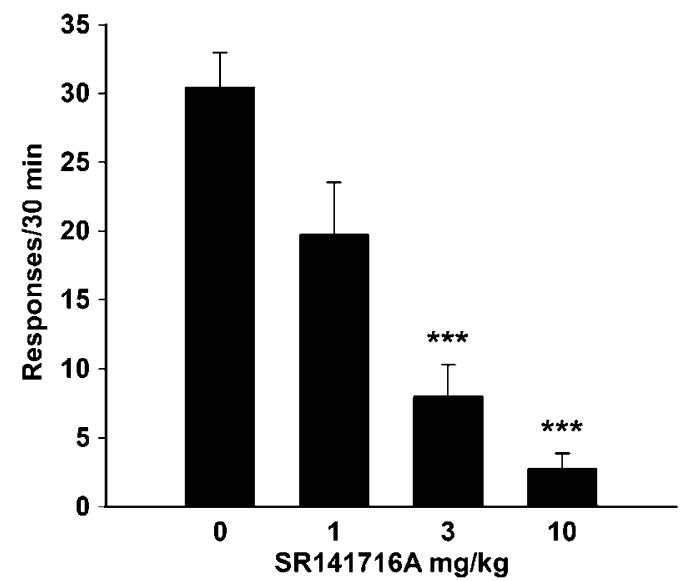

Figure 4 Effect of systemic SRI4I7I6A pre-treatment on ethanol selfadministration. Data are expressed as mean $( \pm$ SEM) responses for $10 \%$ ethanol during 30 -min sessions. $* * * * 0<0.00$ I vs vehicle condition.
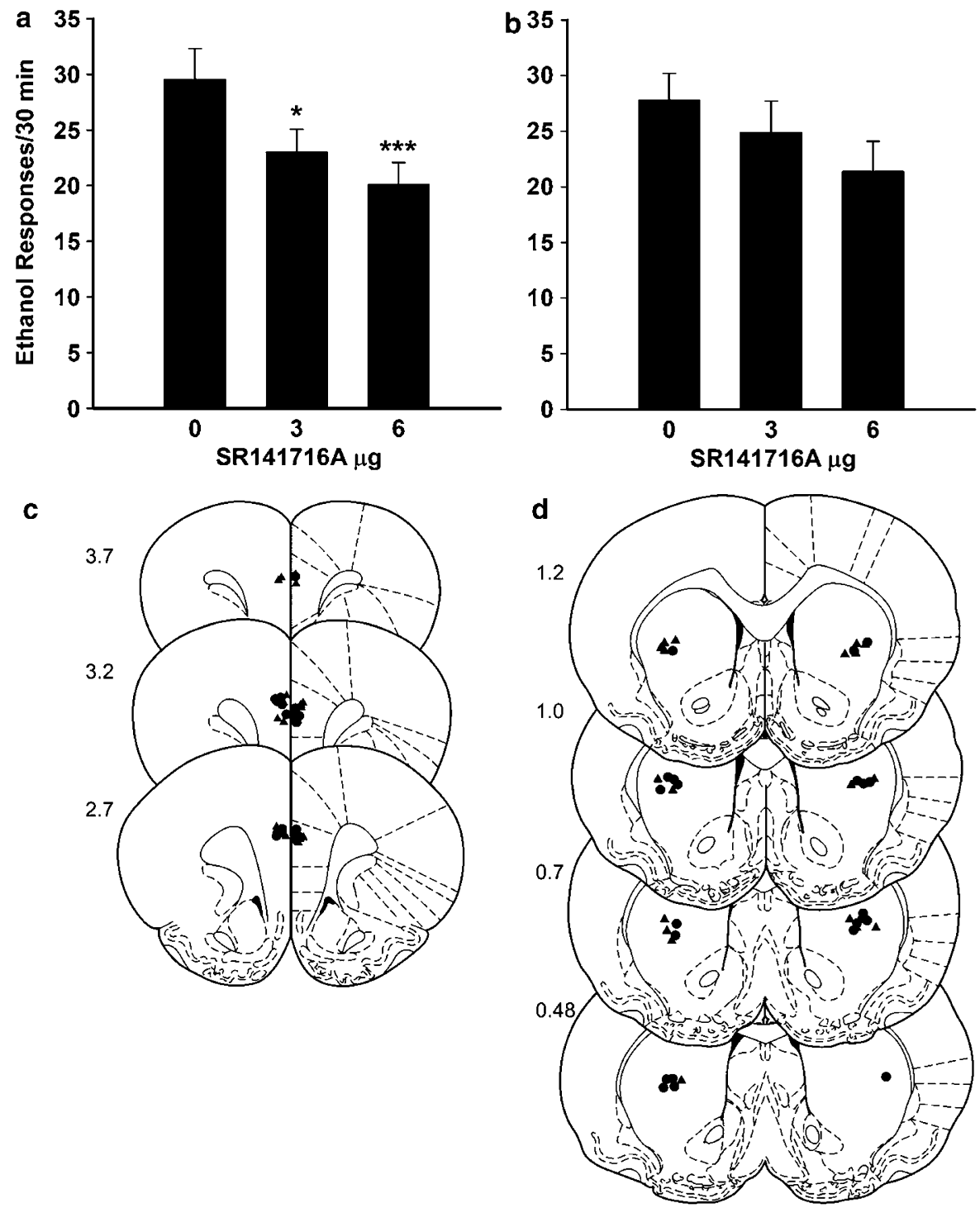

Figure 5 Effects of SRI4I7I6A microinjections into prefrontal cortex (a) and striatum (c) on ethanol responding. Data are expressed as mean ( \pm SEM) responses for $10 \%$ ethanol solution during 30 -min sessions. $* p<0.05$, $* * * *<0.00$ I vs vehicle condition. Locations of the 30-gauge injection cannula tips for the prefrontal and striatal injections are shown in panel (b) and (d), respectively, where the numbers indicate the position (in $\mathrm{mm}$ ) of the coronal sections relative to bregma. 

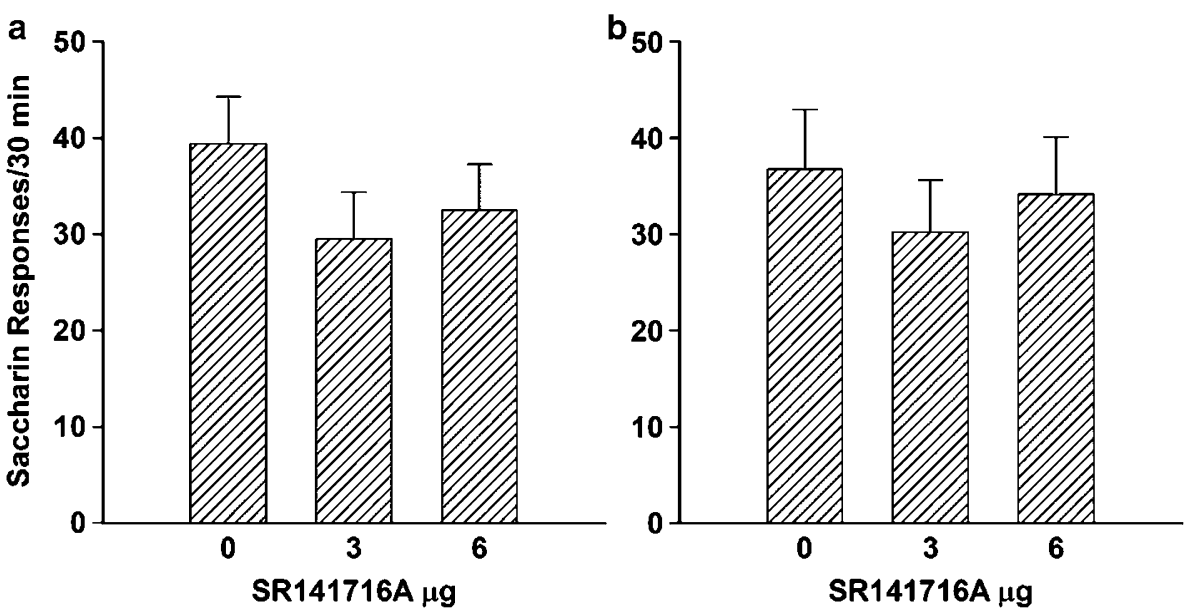

Figure 6 Saccharin self-administration following SRI4I7I6A microinjections into prefrontal cortex (a) and striatum (b). Data are expressed as mean \pm SEM responses for $0.05 \%$ saccharin solution during 30-min sessions; $n=9-10 /$ group. No individual treatment group differed from vehicle-injected controls at $p<0.05$.

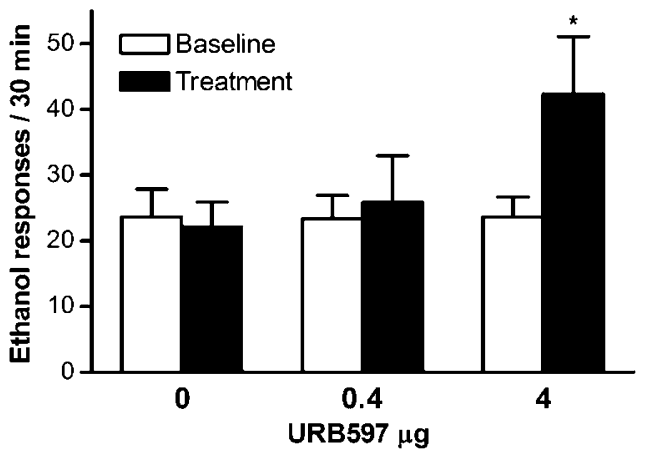

Figure 7 Effects of local injection of the FAAH inhibitor URB597 (0, 0.4, and $4 \mu \mathrm{g})$ in PFC on operant ethanol self-administration. Data are expressed as mean ( \pm SEM) responses for $10 \%$ ethanol during 30-min sessions. * $p<0.05$ Tukey's test post hoc multiple comparisons, $n=7-9 /$ group.

the dorsolateral striatum within the region from 0.48 to $1.2 \mathrm{~mm}$ anterior to bregma. No differences in cannula locations were found between the ethanol and saccharin self-administration groups.

As shown in Figure 6a, although prefrontal SR141716A injections somewhat attenuated saccharin responding $(\mathrm{F}[2,18]=5.72, p<0.01)$, post hoc analysis did not reveal significant effects at any individual SR141716A dose, suggesting that saccharin responding was less sensitive to the effects of SR141716A than ethanol responding. Antagonist injections into striatum (Figure 6b) did not alter saccharin intake $(\mathrm{F}[2,18]=1.46, \mathrm{NS})$. In a separate experiment, repeated intracerebral injections of the vehicle ( $75 \%$ DMSO) had no effects on ethanol responding $(\mathrm{F}[2,12]=0.41, \quad \mathrm{NS} ; \mathrm{F}[2,12]=0.29, \quad \mathrm{NS} ;$ for $\mathrm{PFC}$ and striatum, respectively). This demonstrates that reductions observed after SR141716A were caused by the antagonist, rather than by the repeated vehicle administration.

\section{FAAH Inhibition and Ethanol Self-Administration in Non-Selected Rats}

To mimic the effects of low FAAH activity in the PFC of $\mathrm{AA}$ rats and thus validate its functional consequences for ethanol consumption, the FAAH inhibitor URB597 was injected into the PFC of nonselected Wistar rats. Intra-PFC administration of URB597 increased ethanol responding $(\mathrm{F}[3,39]=5.2, p<0.01$; Figure 7$)$. Post hoc analysis revealed significant differences between the high dose $(4 \mu \mathrm{g}) v s$ either control group $(p<0.05)$ or low dose $(0.4 \mu \mathrm{g} ; p<0.05)$.

\section{DISCUSSION}

\section{Differences in Endocannabinoid Transmission between AA and ANA Rats}

Studies using blockade (Arnone et al, 1997; Rodriguez et al, 1999; Colombo et al, 1998b) or genetic inactivation of CB1 receptors (Hungund et al, 2003; Wang et al, 2003; Naassila et al, 2004) imply endocannabinoid signaling in regulation of ethanol self-administration. Brain expression profiling further points to the possibility that dysregulated expression of endocannabinoid genes, and signal transduction genes under their control, could contribute to high alcohol preference (Rimondini et al, 2002; Arlinde et al, 2004; Derkinderen et al, 2001).

Here, we observed a profound and regionally selective decrease of $F A A H$ expression in the PFC of AA rats. This was accompanied by lower FAAH enzyme activity. To a minor degree, a lower $M A G L$ expression was also found in the PFC of AA rats. The expression of NAPE-PLD, which is the enzyme that releases endocannabinoids from membrane precursors, did not differ between lines. Together with the increased 1-AG and 2-AG levels in the PFC our data thus suggest that endocannabinoid degradation is impaired in this brain region.

Impaired endocannabinoid degradation, leading to a locally elevated endocannabinoid tone within the PFC, might be expected to result in compensatory downregulation of $\mathrm{CB} 1$ receptors. Accordingly, we found decreased CB1 receptor density and coupling in the PFC of AA rats. The decreased CB1 binding and function in PFC were observed in absence of differential $C B 1$ gene expression in this region. Since CB1 receptors are commonly located on axon 
terminals of large projection neurons (Tsou et al, 1998), the observed dissociation between $\mathrm{CB} 1$ binding and expression in $\mathrm{PFC}$ of $\mathrm{AA}$ rats may reflect that $\mathrm{CB} 1$ binding measured is largely due to receptors on afferent fibers originating from other brain regions.

Conversely, a marked reduction of $C B 1$ mRNA was found in dorsal striatum of AA rats, where FAAH and MAGL did not differ between the lines. The lower striatal CB1 expression was not accompanied by decreased binding. A large fraction of $C B 1$ receptor mRNA in the dorsal striatum is committed to receptor expression in striatal projection neurons (Hohmann and Herkenham, 2000). The observed differences of striatal $C B 1$ mRNA levels may thus mainly affect synthesis of $\mathrm{CB} 1$ receptors inserted on termini in striatal output regions.

Several observations relate differences in endocannabinoid systems to differences in alcohol-related phenotypes. High-drinking C57BL/6 mice have lower levels of CB1-binding sites, but higher receptor affinity and coupling than low-drinking DBA/2 mice (Basavarajappa and Hungund, 2002; Hungund and Basavarajappa, 2000). In Wistar rats, a variety of adaptive changes in endocannabinoid systems have been reported following chronic ethanol exposure (Gonzales et al, 2004; Basavarajappa and Hungund, 2005). Most importantly for our present findings, preliminary data were recently reported in abstract form (Walker et al, 2005) that FAAH null mutant mice have increased ethanol consumption. This observation, together with our finding of reduced FAAH expression and activity in the PFC of AA rats, and the increased ethanol responding of Wistar rats after intraprefrontal administration of FAAH inhibitor URB597, provide consistent evidence for the hypothesis that decreased endocannabinoid degradation in key brain regions can lead to elevated ethanol consumption.

\section{Systemic and PFC Injections of SR141716A Reduce Ethanol Self-Administration}

The differential prefrontal endocannabinoid activity shown here adds to a list of neurochemical and genetic traits which have segregated through selective breeding of the AA and ANA lines (Sinclair et al, 1989; Gianoulakis et al, 1992; Arlinde et al, 2004). Most of these are likely results of random cosegregation. In order to demonstrate that a difference between the lines causally contributes to alcohol preference, a demonstration is needed that its pharmacological reversal will also reverse this functional phenotype. In the present study, evidence for such a mechanistic involvement was obtained through the observation that systemic administration of the CB1 antagonist SR 141716A (1-10 $\mathrm{mg} / \mathrm{kg}$, i.p.) produced a profound, dose-dependent reduction in operant ethanol self-administration in AA rats. Increased sensitivity to the effects of SR $141716 \mathrm{~A}$ in AA rats was also suggested, since lower antagonist doses were required for this effect than previously reported in nonselected rats (Rodriguez et al, 1999).

This result is in line with previous studies showing reduced voluntary alcohol intake or operant self-administration in rats by SR 141716A (Arnone et al, 1997; Colombo et al, 1998b; Rodriguez et al, 1999). Consistently with these, CB1 knockout mice have shown greatly reduced ethanol consumption and preference (Hungund et al, 2003; Wang et al, 2003; Naassila et al, 2004). These studies have provided convincing support for the notion that the endocannabinoid system is involved in regulation of ethanol consumption. Our present work extends these findings by providing the first demonstration that preexisting differences in endocannabinoid metabolism contributes to alcohol preference, and that targeting this pre-existing abnormality can reverse this phenotype.

The SR141716A doses active in the present study are in a range known to antagonize a variety of ingestive behaviors. For example, SR141716A suppresses heroin and ethanol selfadministration (Navarro et al, 2001; Rodriguez et al, 1999) and responding for food (Freedland et al, 2000). It also reduces ingestion of ethanol and sucrose solutions (Colombo et al, 1998a,b). However, the effects of SR141716A on ethanol self-administration can possibly be differentiated from those on food intake, since central administration of SR141716A suppresses ethanol self-administration but not feeding, suggesting the possibility that a peripheral site mediates the food intake-suppressant actions of cannabinoid receptor antagonists (Gomez et al, 2002).

The biochemical analysis of AA and ANA lines pointed to the PFC and the dorsal striatum as potential sites for involvement in the effect of SR141716A on ethanol intake. Local intracerebral injections of SR141716A subsequently identified the PFC, but not the dorsal striatum, as a sensitive site in mediating the suppression on ethanol drinking in AA rats. Of note, PFC microinjections suppressed alcohol selfadministration to a lower degree than systemic injections. It should not be overlooked that dense CB1 receptor labeling is also found in other brain regions (Tsou et al, 1998), several of which are known to participate in the regulation of ethanol intake, for example the hippocampus (Tierney et al, 2004) and other cortical or subcortical structures (Carr and Sesack, 1998). With systemic administration of SR141716A, actions in these areas might contribute to the functional effect observed. It should also be noted that the PFC and dorsal striatum have been implicated in habit formation and expression (Killcross and Coutureau, 2003). In contrast to natural reinforcers, ethanol self-administration quickly becomes a stimulus-response habit (Dickinson et al, 2002). Therefore, our observation that CB1 receptor antagonism suppressed ethanol-reinforced behavior more efficiently than that maintained by saccharin could be attributed to effects on motivation, habitual responding, or both.

Taking together the biochemical and pharmacological findings, the picture emerges of a locally elevated PFC endocannabinoid tone due to impaired degradation, in turn leading to compensatory downregulation of receptor density and transduction. The compensation seems to be incomplete, and an elevated endocannabinoid tone in the PFC continues to contribute to high alcohol preference and self-administration, reversed by local administration of antagonist.

\section{PFC Endocannabinoids in Regulation of Ethanol Consumption}

Neural mechanisms underlying the PFC endocannabinoid regulation of ethanol consumption are not known, but are likely related to interaction with either the putative primary targets of ethanol, that is, glutamatergic and GABAergic 
systems, or with dopaminergic and opioidergic pathways of the classical reward circuits. The endogenous cannabinoid system is a potent local regulator of GABAergic and glutamatergic transmission through retrograde messenger actions of endocannabinoids on $\mathrm{CB} 1$ receptors located in GABA and glutamate axon terminals (Freund et al, 2003). These effects are mediated, among others, through metabotropic glutamate receptor-dependent activation of endocannabinoid release located in prefrontal pyramidal neurons (Doherty and Dingledine, 2003; Barbara et al, 2003). Furthermore, in vivo microdialysis demonstrates that the main cannabinoid constituent of marihuana, $\Delta^{9}$-THC, reduces extracellular GABA in PFC (Pistis et al, 2002). Together, this suggests a common mechanism for endocannabinoids to modulate neurotransmission via a local GABAergic interneuronal network.

\section{Convergence of Animal and Human Studies}

Our findings point to an overactive endocannabinoid system in the PFC of AA rats, with only partial compensation through downregulated $\mathrm{CB} 1$ signaling. These results closely parallel the recent description of increased vulnerability to drug use and alcoholism in humans bearing a nucleotide polymorphism in the FAAH gene (Sipe et al, 2002), and reduced FAAH protein levels as well as activity (Chiang et al, 2004). Thus, genetic variation in the FAAH gene may predispose to elevated voluntary ethanol consumption and alcoholism.

In conclusion, we show that an overactive and partially desensitized endocannabinoid transmission is present in the PFC of AA rats, and contributes to their phenotype of high ethanol self-administration. This phenotype can be mimicked by FAAH inactivation in the PFC of normal Wistar rats. These results suggest that pre-existing differences in endocannabinoid transmission can confer a susceptibility to high alcohol drinking. They further point to the PFC as a key structure in this trait. Finally, they provide further support for the utility of pharmacologically targeting the endocannabinoid system for treatment of alcoholism.

\section{ACKNOWLEDGEMENTS}

This work was supported by an EC Grant (TARGALC, QLRT-2001-01048). Additional funding came from FIS (Red RTA G03/05 and CIEN (C03/06), KI Research Grant and SLSS Found. We are grateful to Siv Eriksson for technical assistance.

\section{REFERENCES}

Arlinde C, Sommer W, Bjork K, Reimers M, Hyytia P, Kiianmaa K et al (2004). A cluster of differentially expressed signal transduction genes identified by microarray analysis in a rat genetic model of alcoholism. Pharmacogenomics J 4: 208-218.

Arnone M, Maruani J, Chaperon F, Thiebot MH, Poncelet M, Soubrie $P$ et al (1997). Selective inhibition of sucrose and ethanol intake by SR 141716, an antagonist of central cannabinoid (CB1) receptors. Psychopharmacology (Berlin) 132: 104-106.

Barbara JG, Auclair N, Roisin MP, Otani S, Valjent E, Caboche J et al (2003). Direct and indirect interactions between cannabi- noid $\mathrm{CB} 1$ receptor and group II metabotropic glutamate receptor signalling in layer $\mathrm{V}$ pyramidal neurons from the rat prefrontal cortex. Eur J Neurosci 17: 981-990.

Basavarajappa BS, Hungund BL (2002). Neuromodulatory role of the endocannabinoid signaling system in alcoholism: an overview. Prostag Leukot Essent Fatty Acids 66: 287-299.

Basavarajappa BS, Hungund BL (2005). Role of the endocannabionoid system in the development of tolerance to alcohol. Alcohol Alcohol 40: 24.

Caberlotto L, Rimondini R, Hansson A, Eriksson S, Heilig M (2003). Corticotropin-releasing hormone (CRH) mRNA expression in rat central amygdala in cannabinoid tolerance and withdrawal: evidence for an allostatic shift? Neuropsychopharmacology 25: 1564-1569.

Carr DB, Sesack SR (1998). Callosal terminals in the rat prefrontal cortex: synaptic targets and association with GABA-immunoreactive structures. Synapse 29: 193-205.

Chiang KP, Gerber AL, Sipe JC, Cravatt BF (2004). Reduced cellular expression and activity of the P129T mutant of human fatty acid amide hydrolase: evidence for a link between defects in the endocannabinoid system and problem drug use. Hum Mol Genet 13: 2113-2119.

Cloninger CR (1987). Neurogenetic adaptive mechanisms in alcoholism. Science 236: 410-416.

Colombo G, Agabio R, Diaz G, Lobina C, Reali R, Gessa GL (1998a). Appetite suppression and weight loss after the cannabinoid antagonist SR 141716. Life Sci 63: L113-L117.

Colombo G, Agabio R, Fa M, Guano L, Lobina C, Loche A et al (1998b). Reduction of voluntary ethanol intake in ethanolpreferring sP rats by the cannabinoid antagonist SR-141716. Alcohol Alcoholism 33: 126-130.

Derkinderen P, Ledent C, Parmentier M, Girault JA (2001). Cannabinoids activate p38 mitogen-activated protein kinases through CB1 receptors in hippocampus. J Neurochem 77: 957-960.

Desarnaud F, Cadas H, Piomelli D (1995). Anandamide amidohydrolase activity in rat brain microsomes. Identification and partial characterization. J Biol Chem 270: 6030-6035.

Dickinson A, Wood N, Smith JW (2002). Alcohol seeking by rats: action or habit? Q J Exp Psychol B 55: 331-348.

Doherty J, Dingledine R (2003). Functional interactions between cannabinoid and metabotropic glutamate receptors in the central nervous system. Curr Opin Pharmacol 3: 46-53.

Enoch MA, Goldman D (2001). The genetics of alcoholism and alcohol abuse. Curr Psychiatr Rep 3: 144-151.

Freedland CS, Poston JS, Porrino LJ (2000). Effects of SR141716A, a central cannabinoid receptor antagonist, on food-maintained responding. Pharmacol Biochem Behav 67: 265-270.

Freund TF, Katona I, Piomelli D (2003). Role of endogenous cannabinoids in synaptic signaling. Physiol Rev 83: 1017-1066.

Gianoulakis C, De Waele JP, Kiianmaa K (1992). Differences in the brain and pituitary beta-endorphin system between the alcoholpreferring AA and alcohol-avoiding ANA rats. Alcohol Clin Exp Res 16: 453-459.

Giuffrida A, Rodriguez DF, Piomelli D (2000). Quantification of bioactive acylethanolamides in rat plasma by electrospray mass spectrometry. Anal Biochem 280: 87-93.

Gomez R, Navarro M, Ferrer B, Trigo JM, Bilbao A, Del AI et al (2002). A peripheral mechanism for CB1 cannabinoid receptor-dependent modulation of feeding. I Neurosci 22: 9612-9617.

Gonzales S, Valenti M, deMiguel R, Fezza F, Fernandez-Ruiz J, DiMarza V et al (2004). Changes in endocannabinoid contents in reward-related brain regions of alcohol-exposed rats, and their possible relevance to alcohol relapse. Br J Pharmacol 143: $455-464$

Hansson AC, Sommer W, Rimondini R, Andbjer B, Stromberg I, Fuxe K (2003). c-fos reduces corticosterone-mediated effects on 
neurotrophic factor expression in the rat hippocampal CA1 region. J Neurosci 23: 6013-6022.

Herkenham M, Lynn AB, Little MD, Johnson MR, Melvin LS, de Costa BR et al (1990). Cannabinoid receptor localization in brain. Proc Natl Acad Sci USA 87: 1932-1936.

Hirst RA, Almond SL, Lambert DG (1996). Characterisation of the rat cerebellar CB1 receptor using SR141716A, a central cannabinoid receptor antagonist. Neurosci Lett 220: 101-104.

Hohmann AG, Herkenham M (2000). Localization of cannabinoid $\mathrm{CB}(1)$ receptor mRNA in neuronal subpopulations of rat striatum: a double-label in situ hybridization study. Synapse 37: 71-80.

Holm S (1979). A simple sequentially rejective multiple test procedure. Scand J Stat 6: 65-70.

Houchi H, Babovic D, Pierrefiche O, Ledent C, Daoust M, Naassila M (2005). CB1 receptor knockout mice display reduced ethanolinduced conditioned place preference and increased striatal dopamine D2 receptors. Neuropsychopharmacology 30: 339-349.

Hungund BL, Basavarajappa BS (2000). Distinct differences in the cannabinoid receptor binding in the brain of C57BL/6 and DBA/ 2 mice, selected for their differences in voluntary ethanol consumption. J Neurosci Res 60: 122-128.

Hungund BL, Szakall I, Adam A, Basavarajappa BS, Vadasz C (2003). Cannabinoid CB1 receptor knockout mice exhibit markedly reduced voluntary alcohol consumption and lack alcohol-induced dopamine release in the nucleus accumbens. J Neurochem 84: 698-704.

Johnson BA, Roache JD, Javors MA, DiClemente CC, Cloninger CR, Prihoda TJ et al (2000). Ondansetron for reduction of drinking among biologically predisposed alcoholic patients - a randomized controlled trial. J Am Med Assoc 284: 963-971.

Kathuria S, Gaetani S, Fegley D, Valino F, Duranti A, Tontini A et al (2003). Modulation of anxiety through blockade of anandamide hydrolysis. Nat Med 9: 76-81.

Killcross S, Coutureau E (2003). Coordination of actions and habits in the medial prefrontal cortex of rats. Cereb Cortex 13: 400-408.

Lutz B (2002). Molecular biology of cannabinoid receptors. Prostag Leukot Essent Fatty Acids 66: 123-142.

Mailleux P, Vanderhaeghen JJ (1992). Distribution of neuronal cannabinoid receptor in the adult rat brain: a comparative receptor binding radioautography and in situ hybridization histochemistry. Neuroscience 48: 655-668.

Matsuda LA, Bonner TI, Lolait SJ (1993). Localization of cannabinoid receptor mRNA in rat brain. J Comp Neurol 327: 535-550.

Matsuda LA, Lolait SJ, Brownstein MJ, Young AC, Bonner TI (1990). Structure of a cannabinoid receptor and functional expression of the cloned cDNA. Nature 346: 561-564.

McBride WJ, Li TK (1998). Animal models of alcoholism: neurobiology of high alcohol-drinking behavior in rodents. Crit Rev Neurobiol 12: 339-369.

Mokdad AH, Marks JS, Stroup DF, Gerberding JL (2004). Actual causes of death in the United States, 2000. JAMA 291: 1238-1245.

Möller C, Wiklund L, Thorsell A, Hyytia P, Heilig M (1997). Decreased measures of experimental anxiety in rats bred for high alcohol preference. Alcohol Clin Exp Res 21: 656-660.

Naassila M, Pierrefiche O, Ledent C, Daoust M (2004). Decreased alcohol self-administration and increased alcohol sensitivity and withdrawal in CB1 receptor knockout mice. Neuropharmacology 46: 243-253.

Navarro M, Carrera MR, Fratta W, Valverde O, Cossu G, Fattore L et al (2001). Functional interaction between opioid and cannabinoid receptors in drug self-administration. J Neuroscience 21: 5344-5350.

Oslin DW, Berrettini W, Kranzler HR, Pettinati H, Gelernter J, Volpicelli JR et al (2003). A functional polymorphism of the mu-opioid receptor gene is associated with naltrexone response in alcohol-dependent patients. Neuropsychopharmacology 28: 1546-1552.

Paxinos G, Watson C (1986). The Rat Brain in Stereotaxic Coordinates. Academic Press: San Diego.

Pistis M, Ferraro L, Pira L, Flore G, Tanganelli S, Gessa GL et al (2002). Delta(9)-tetrahydrocannabinol decreases extracellular GABA and increases extracellular glutamate and dopamine levels in the rat prefrontal cortex: an in vivo microdialysis study. Brain Res 948: 155-158.

Poncelet M, Maruani J, Calassi R, Soubrie P (2003). Overeating, alcohol and sucrose consumption decrease in CB1 receptor deleted mice. Neurosci Lett 343: 216-218.

Rimondini R, Arlinde C, Sommer W, Heilig M (2002). Long-lasting increase in voluntary ethanol consumption and transcriptional regulation in the rat brain after intermittent exposure to alcohol. FASEB J 16: 27-35.

Rinaldi-Carmona M, Barth F, Heaulme M, Shire D, Calandra B, Congy C et al (1994). SR141716A, a potent and selective antagonist of the brain cannabinoid receptor. FEBS Lett 350: 240-244.

Rodriguez DF, Navarro M, Gomez R, Escuredo L, Nava F, Fu J et al (2001). An anorexic lipid mediator regulated by feeding. Nature 414: 209-212.

Rodriguez DF, Roberts AJ, Bilbao A, Koob GF, Navarro M (1999). Cannabinoid receptor antagonist SR141716A decreases operant ethanol self administration in rats exposed to ethanol-vapor chambers. Chung-Kuo Yao Li Hsueh Pao-Acta Pharmacol Sinica 20: 1109-1114.

Sim LJ, Hampson RE, Deadwyler SA, Childers SR (1996). Effects of chronic treatment with delta9-tetrahydrocannabinol on cannabinoid-stimulated [35S]GTPgammaS autoradiography in rat brain. J Neurosci 16: 8057-8066.

Sinclair JD, Le AD, Kiianmaa K (1989). The AA and ANA rat lines, selected for differences in voluntary alcohol consumption. Experientia 45: 798-805.

Sipe JC, Chiang K, Gerber AL, Beutler E, Cravatt BF (2002). A missense mutation in human fatty acid amide hydrolase associated with problem drug use. Proc Natl Acad Sci USA 99: 8394-8399.

Tierney PL, Degenetais E, Thierry AM, Glowinski J, Gioanni Y (2004). Influence of the hippocampus on interneurons of the rat prefrontal cortex. Eur J Neurosci 20: 514-524.

Tsou K, Brown S, Sanudo-Pena MC, Mackie K, Walker JM (1998). Immunohistochemical distribution of cannabinoid CB1 receptors in the rat central nervous system. Neuroscience 83: 393-411.

Walker D, Blednov BF, Cravatt BF, Harris RA (2005). Increased ethanol consumption in mice lacking fatty acid amide hydrolase: Implications for endocannabinoids. Abstract at the Annual Meeting of the Research Society for Alcoholism. Alcohol Clin Exp Res 29: 99A.

Wang L, Liu J, Harvey-White J, Zimmer A, Kunos G (2003). Endocannabinoid signaling via cannabinoid receptor 1 is involved in ethanol preference and its age-dependent decline in mice. Proc Natl Acad Sci USA 100: 1393-1398. 